\title{
Rethinking Engineering Education
}

\author{
Claudio R. Brito \\ President of IEEE Education Society \\ President of COPEC - Science and Education Research \\ Council \\ Santos, Brazil \\ drbrito@copec.eu
}

\author{
Rosa M. Vasconcelos
}

Board of Governors of IEEE Education Society

President of Pedagogic Council of Engineering College at

University of Minho

Guimarães, Portugal

rosa@det.uminho.pt

\section{Henrique D. Santos}

Vice President for Conferences of IEEE Education Society Director of Information Systems Department at University of Minho

Guimarães, Portugal

hsantos@dsi.uminho.pt

\author{
Melany M. Ciampi \\ President of WCSEIT - World Council on Systems \\ Engineering and Information Technology \\ Secretary of IEEE Education Society \\ Braga, Portugal \\ drciampi@copec.eu
}

\author{
Luis A. Amaral \\ President of CCG - Computer Graphics Centre \\ Professor of Information Systems Department at University \\ of Minho \\ Guimarães, Portugal \\ amaral@dsi.uminho.pt \\ Victor A. Barros \\ Intersociety Cooperation Committee of IEEE Education \\ Society \\ Executive Secretary of COPEC - Science and Education \\ Research Council \\ Jataí, Brazil \\ victor@,copec.eu
}

\begin{abstract}
The Professional of today needs to acquire a dynamic ability to absorb information, adjust to organizational goals, and navigate in a complex work environment. For this reason, a classic approach seems to be more useful for the demands of today's job market. It is at least interesting to notice, that the classic approach is being neglected, at a time when its product might be more interesting than ever. The Engineering Education Team of COPEC - Science and Education Research Council has designed a program that is knowledge centered and specially challenging, which integrates classical engineering approaches and real experience in order to achieve a high level of engineers ready to perform as professionals or researchers. It aims to form the Engineer - a professional that is capable to learn for life and be creative in many ways.
\end{abstract}

Keywords-learning tools; best practices; work market; intellectual skills; knowledge-centered.

\section{INTRODUCTION}

It has been a challenge that engineering colleges have been facing and it is time to rethink engineering education - if students are taught the skills of learning by themselves, then they will continue to learn on their own for the rest of their lives. How is this possible? By the well-walked path of the tried and proven - the classical method of educating engineers.
Let's face reality, sometimes it is necessary to go back to basics and so it seems that the best way is the classical education, not as synonym of Christian education, but as the education with solid basis of knowledge in basic sciences and basic sciences of engineering. Students then will finish their course equipped with the right tools and a strong capacity of learning. Classical education then, in this sense, is a life-long process of applying the "tools of learning" - tools that are skills entailed in basic sciences, engineering basic sciences, and specific of engineering, which travels with the student through her/his career as a professional or as an academic. In other words, the market seems to be ready for those who obtain a general engineering education and develop adaptable skills that will serve them while their world continues to evolve [1].

The adopted educational method and approaches of a program have to lead the students to notice that education is not an abstract term. It is established in cultural economic, individual, philosophical, scientific and social advancement. In other words, education is the mean for developing the mind for the betterment of the individual and society.

It is also important to show students that advances in science and technology mean that the world will continue to change rapidly, so that the knowledge learned by students in specific careers will have a short lifespan. In contrast, those who achieve a general education will develop adaptive skills, which will serve them while their world evolves. Beside this, 
since people tend to change jobs and occupational fields several times throughout their lives, it is important to acquire a dynamic ability to absorb information, to adjust to organizational goals, and to navigate through complex work relationships; for this reason, a classical approach seems more useful for today's work market.

Another important point is the integration of Internships and practical projects in the program, which are relevant for both: student's studies and the real work scenario. The internship and the project offer opportunities to take the skills they are developing in the classroom to the real world. So, Schools have to provide internships in companies, in the field of the student's choices during the fourth and fifth year of college, depending on the length of the program. They become then, at that time, more prepared to face these challenges [2].

\section{NeW Market Demands Fostering NeW WAys OF FORMING ENGINEERS}

Graduates' Employability is from the responsibility of both, universities and employers, however, both fail in many ways, because they also have to face the mutant technological environment in which business and research is immersed in. The case is that mainly universities have to consider the mission of preparing students for their first job and/or for lifelong careers. But universities have now other missions, besides making sciences advance. They have become development hubs in the regions where they are and promoters of social communities. These new tasks mean "many eggs in one basket". So, the formation of good professionals is essential because it is an important part of the core existence of universities.

The main reason why the program described in this paper has been designed is that the engineering school of a private university decided to invest in a new civil engineering program, instead of opening a new program in another field, once this one is still the most required course by young people in the region, once the country, by its size, has still a lot to build.

In order to overcome the difficulties of the hard competition and external evaluation of programs, the university has hired COPEC - Science and Education Research Team for Engineering Education, which has designed a program, which is knowledge cantered and specially challenging. It is a program that integrates classical engineering approaches and real experience, in order to achieve a high level of engineers, ready to perform as professionals or researchers. Their goal is to train Engineers able to learn for life and be creative in many ways. It is important to have successful alumni that bring more prestige and attracts more students.

The civil engineering program has been specially designed and aims to become the best one in the region, in order to attract more students. Despite being a relatively small region, it has five other universities offering the same program of civil engineering. Added to this, there is the task of facing the external evaluation process by the Ministry of Education, which has been having a huge impact in university programs [3].

\section{TIMELESS EDUCATION}

For long, and today it is not an exception, the classical/general education (and here as opposed to progressive education) appears to be a type of education that has a history of over 2500 years in the West. It is a timeless education that resists time. It began in ancient Greece, was adopted widespread by the Romans, reduced after the fall of Rome, made a slow but steady recovery during the Middle Ages, and was again brought to perfection in the Italian Renaissance. The main objective of classical education, in any level, is to form the whole person, according to timeless intrinsic values; it is a very effective way to form free citizens, as opposed to controlled citizens.

The timeless classic view of education states, essentially, that human beings are intelligent beings, which means that human beings want to know things, more specifically to know what things are and how they work. It is primarily focused on knowledge and not student-cantered. Information technology provides opportunities to make learning material more visual, interactive and accessible, significant intellectual effort is required, regardless of the format of the material. Students must read, think, write and must analyze. No matter how advanced and interactive the tools and techniques are presently, learning still requires hard work [4].

History shows that the classic engineering was responsible for the appearance of weapons, fortifications, roads, bridges, canals, tools, etc. In the eighteenth century, the first engineering schools emerged in France. They are: the École des Ponts et Chaussées (1747), the École de Mines (1783) and the École Polytechnique (1794), it was the period when Science married Engineering. They all belong to the group of French Schools that constitute mostly the so-called "generalist" Grandes Écoles, and the leading ones, of these groups, constitute the major part of the French scientific elite education system [5].

Currently, what has been seen in the science research field is that research work is not based on a top-down commandand-control hierarchy anymore. In this new virtual and complex system, scientists combine and recombine in research teams, based not on academic discipline or institutional affiliation or geographic location, but on the unique requirements of the problems they want to address. It means that researchers do not have to be in the same place of their collaborators, nor have they to be in the same place as the problems they seek to solve. There are international networks, which are more important to individual faculty members, than their departmental or institutional ties, since this network enlarges the possibilities of research and career success [6].

Besides this aspect, the time is coming, when most people will have a number of jobs, before middle age, and when many jobs have not yet been developed; the question is: how can educational institutions form or train in a manner that may not yet exist? The classical/general education curriculum provides an answer. 


\section{Chosen Education Style}

The Second World War is a landmark, the cold war and the run for the moon have driven education to a big change, added to the enlargement of students in university. These changes were necessary, however, due to the challenging and mutant educational environment, as well as the global market and the scientific and technologic new achievements, it is rather difficult to figure out what kind of engineers will be necessary. In order to face the new challenges, the classical engineering training/formation is an approach that provides new engineers the right tools to perform and to learn for life [7].

As mentioned previously, regarding the high competition for success, private universities struggle to attract good students for their programs, once it guarantees the continuity of the colleges and programs. The external evaluation that programs and colleges have been facing, push them to enhance the quality of the programs that they offer. It is a positive fact that fosters programs and investments in laboratories and libraries, besides teachers.

For these reasons, to attend the necessities of an engineering college of a private university, COPEC's team has chosen to propose the pursuit of a classical/general education approach for the civil engineering program and so form the "Engineer". The engineer who has knowledge and self-taught skills - a professional who can think, calculate, analyze, understand, solve problems and follow through a wide range of perspectives - social, economic and of sustainability among others. It is a way to attract good students to their programs, as it ensures the continuity of colleges and programs.

It is essentially, what says a famous and very appreciated Chinese Proverb - "Give a man a fish and you feed him for a day. Teach a man to fish and you feed him for a lifetime".

The program started in 2014 and the enrolment was low, comparing with previous years. However, three years later, the results have been very positive, taking into account the trend of engineering programs, choices in young generation and the competitiveness in the region.

\section{FACING GLOBAL MARKET COMPETITIVE ENVIRONMENT}

The present proposal of a classic engineering program, that means a classic curriculum, came as a response to develop a new educational approach with the goal of strengthening a civil engineering course that saw its enrolment declining each year.

The key elements are:

- have a well-conceived, coherent, sequential curriculum;

- have all courses with strong and pertinent knowledge;

- adjust other parts of the education system of the program to support the goals of learning;

- provide teachers with a carefully conceived curriculum, filled with challenging texts and materials;

- provide students where they are going and how they are going to get there.
To reach the objective, it is necessary to challenge students to acquire the knowledge that they really need to become engineers; a professional capable to do any work and overcome the unpredictable future, when it is becoming difficult to anticipate the new professions and opportunities that will be needed [8].

The curriculum has been set and discussed with a set of professors, specialists in their fields of expertise, and in accordance with the Law of the Ministry of Education, the organization that regulates and accredits University and School Programs.

The curriculum is organized in order to provide basic sciences courses to students, taught during the first two years; followed by basic sciences courses of engineering, deployed during the second and third years and the specific courses of engineering, in this case, civil engineering, with emphasis in concrete constructions and eco building construction (following the trend of sustainable buildings - energy efficiency and use of low emission of $\mathrm{Co} 2$ materials) [9].

The figure below shows a block of different courses that were added and that have been taught in a period that has been named as Pre - Program. This happens two weeks prior to the year scheduled, when students have classes of Language usage, Instrumental English (usage of technical English), Mathematics (review of high school content) and Psychology (aspects of the competitive and demanding pressure environment).

So the program design is as follows:
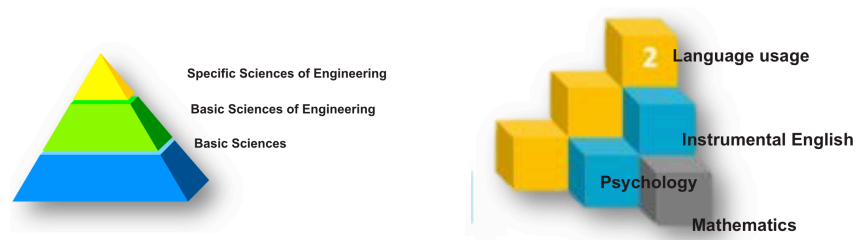

Figure 1. Block of different courses that were added in a period that has been named as Pre-Program.

Another important aspect of the program are the teachers who were especially selected for the program. A very qualified academic who also attends relevant conferences, networks with peers and engages in continuing education to stay at the forefront of its specialty, teachers who motivate, inspire and lead.

According to the project frame, there is space for other activities that can particularly motivate the future engineers to keep going and investing in their careers and to be aware of the difficulties that everybody has to face along the way. This particular aspect has to be developed.

\section{THE CURRICULUM CHARACTERISTICS}

Following, there is a chart of the basic cycle curriculum, that covers seven subjects in the first semester of the students' admission year in the Civil Engineering course, and eight subjects in the second semester, totaling 27 credits in the first semester and 28 in the second semester. The content of 
subjects is taught deeply and with intense exercise sessions. It starts in the pre-program and lasts for all years.

Table 1. Basic Cycle Curriculum.

\begin{tabular}{|c|c|c|c|c|c|}
\hline & Discipline & $\mathbf{C C}$ & CW & TC & OC \\
\hline \multirow{8}{*}{$\begin{array}{c}1^{\text {st }} \\
\text { Semeste } \\
r\end{array}$} & General Physics for Engineering I & 4 & 0 & 4 & \\
\hline & Experimental Physics for Engineering I & 2 & 0 & 2 & \\
\hline & Introduction to Engineering Computing & 4 & 0 & 4 & \\
\hline & Differential and Integral Calculus for Engineering I & 4 & 0 & 4 & \\
\hline & Linear Algebra for Engineering I & 4 & 0 & 4 & \\
\hline & Design for Engineering I & 2 & 0 & 2 & \\
\hline & Introduction to Engineering & 3 & 0 & 3 & \\
\hline & General Technological Chemistry & 4 & 0 & 4 & 27 \\
\hline \multirow{8}{*}{$\begin{array}{c}2^{\text {nd }} \\
\text { Se } \\
\text { mes } \\
\text { ter }\end{array}$} & General Physics for Engineering II & 4 & 0 & 4 & \\
\hline & Experimental Physics for Engineering II & 2 & 0 & 2 & \\
\hline & Numerical Calculus & 4 & 0 & 4 & \\
\hline & $\begin{array}{l}\text { Differential and Integral Calculus for Engineering } \\
\text { II }\end{array}$ & 4 & 0 & 4 & \\
\hline & Linear Algebra for Engineering II & 4 & 0 & 4 & \\
\hline & Design for Engineering II & 2 & 0 & 2 & \\
\hline & Mechanics I & 4 & 0 & 4 & \\
\hline & Introduction to Materials Science for Engineering & 4 & 0 & 4 & 28 \\
\hline
\end{tabular}

\section{FIRST RESULTS}

2016 is the third year of this Civil Engineering program and the results are the following:

Table 2. Civil Engineering program.

\begin{tabular}{|c|c|c|c|}
\hline YEAR & $\begin{array}{c}\text { Total of students that have } \\
\text { entered in the Civil Engineering } \\
\text { Program }\end{array}$ & $\begin{array}{c}\text { Number of students of civil } \\
\text { engineering that have opted for } \\
\text { the Classical Engineering } \\
\text { Program }\end{array}$ & $\begin{array}{c}\text { \% of } \\
\text { enrollme } \\
\text { nt rate }\end{array}$ \\
\hline $\mathbf{2 0 1 4}$ & 180 students & 89 students & $49.44 \%$ \\
\hline $\mathbf{2 0 1 5}$ & 180 students & 100 students & $55.56 \%$ \\
\hline $\mathbf{2 0 1 6}$ & 180 students & 136 students & $75.56 \%$ \\
\hline
\end{tabular}

The table is based only on the enrolment number of students in the first and following years of program.

\section{PROGRAM EXPECTED OUTCOMES}

The initiative proposes specific learning outcomes and competencies such as:

- Applied learning: used by students to demonstrate what they can do with what they know.

- Intellectual skills: used by students to think critically and analytically about what they learn.

- Specialized knowledge: the knowledge students demonstrate about their individual fields of study.

- Broad knowledge: transcends the typical boundaries of students of higher education and encompasses all learning in broad areas through their solid knowledge in basic sciences and specific of engineering.

- Civic learning: enables students to respond to social, environmental, and economic challenges at local, national and global levels [10].

\section{DisCUSSIONS AND CONCLUSIONS}

The combination of a classical curriculum with modern technology and internships results in a high quality formation, where students are engaged and prepared to face the challenging career development in this century. Classical education provides professionals tools that enable them to respond quickly to the changing work market and the unpredictable new professional expertise fostered by scientific and technological development.

Unfortunately, there is a trend in engineering colleges to teach less mathematics and physics content, once, particularly, these are the subjects that hold students back. This seems to be one of the causes of such a poor students' performance. Presently there are no students' surveys to determine if this group is trained better and/or has better skills, however it is estimated that during the internship period they show better knowledge of mathematics, which seems to enhance their performance. This is the conclusion of a survey applied, every three months, to institutions that received the $3^{\text {rd }}$ year students, in the second semester of 2016, since interns have showed this difference when institutions graded students' working performance. By better performance, it means that students can cope easier with the challenges and difficulties of problem solving process and they have a better understanding of mathematical modelling, very important to search the best solutions.

The design and implementation of this program has been very positive so far. The first group of students, who will graduate in 2018, the students who are in their internships, in the 4th year, have showed better performance comparing to those in the other program, which is a first step to success. It means that students have better grades mainly in the second and third years of the program so far. The Pre - Program, in special, has a good effect in students, once it provides them some elements that they can use such as Psychology and technical English.

The internship period that is recommended in the 4th year of the program has just started and the engineering college has been working to help students to find good Internships. It is crucial to advise them and to ensure proper conditions, in accordance to the laws, in order to avoid waste of time and possible misuse of qualified labor force.

This knowledge centered program is responding very positive in terms of students' enrolment, and it is necessary to undertake a survey to figure out what elements are influencing students to opt for this kind of education: the different approach, the strong knowledge basis or the possibilities of performing in any field of civil engineering along the career of their choice, once the present market is mutant and challenging. This is the next step for 2017, to perform a research, taking place during the second semester of the year. In fact, the results will be known in the beginning of 2018. The goal is to refine the program advertisement, as well as to provide an input of what is really working well and what is not.

\section{ACKNOWLEDGMENT}

This work is financed by FEDER funds through the Competitivity Factors Operational Programme - COMPETE: POCI-01-0145-FEDER-007043 and by national funds through FCT - Foundation for Science and Technology within the scope of the project POCI-01-0145-FEDER-007136 and project UID/CEC/00319/2013. 


\section{REFERENCES}

[1] M. S. Knowles, E. F. Holton III, and R. A. Swanson, The adult learner: The definitive classic in adult education and human resource development. Routledge, 2014.

[2] M. J. de Vries, L. Gumaelius, and I.-B. Skogh, "Pre-university engineering education," in Pre-university Engineering Education, Springer, 2016, pp. 13-25.

[3] S. Amat, S. Busquier, M. Jose Legaz, and J. Ruiz, "Unifying the classical approach with new technologies: An innovative proposal for teaching mathematics in engineering," Int. J. Interact. Multimed. Artif. Intell., vol. 3, no. 4, SI, pp. 17-19, 2015.

[4] P. G. Altbach, "What Higher Education Does Right: A Millennium Accounting," Chang. Mag. High. Learn., vol. 32, no. 4, pp. 52-52, 2015.

[5] P. C. Wankat and F. S. Oreovicz, Teaching Engineering. Purdue University Press, 2015.

[6] E. Pâmîntaş, "Higher Technical Education - Research vs. Education. Technique Of Teaching, Between Classical And Modern," ACTA Univ. Cibiniensis, vol. 66, no. 1, 2015.
[7] C. da R. Brito, M. M. Ciampi, R. M. Vasconcelos, L. A. M. Amaral, and V. F. A. Barros, "Engineering Adventure for Youth Generations," in 2016 ASEE Annual Conference \& Exposition Proceedings, 2016.

[8] C. da R. Brito, M. M. Ciampi, V. F. A. Barros, L. A. M. Amaral, and R. Vasconcelos, "Engineering the engineering program: The year of discovery," in 2016 IEEE Frontiers in Education Conference (FIE), 2016, pp. 1-4.

[9] C. da R. Brito, M. M. Ciampi, L. A. M. Amaral, R. Vasconcelos, and V. F. A. Barros, "The Year of Discovery," in 44th SEFI Annual Conference, 2016.

[10] C. da R. Brito, M. M. Ciampi, L. A. M. Amaral, R. Vasconcelos, and V. F. A. Barros, "Creating New Learning Environment to Foster Enrollment in Engineering Programs," in Interactive Collaborative Learning: Proceedings of the 19th ICL Conference - Volume 1, M. E. Auer, D. Guralnick, and J. Uhomoibhi, Eds. Cham: Springer International Publishing, 2017, pp. 455-463. 